\title{
Ghana's Deposit Protection Act: Are Depositors Protected?
}

\author{
Isaac Osei-Owusu* \\ Isaac Osei Owusu LLM (GW), LLB (GIMPA), MBA (Kalaidos University of Applied Science), Managing \\ Partner at Versus Legal \& Advocacy, Accra \\ *Theophilus Tawiah \\ (B.Com (Cape Coast), LLB (Leicester) LPC (De Montfort) LLM (Cardiff), MCIT, is a Law Lecturer at UPSA \\ Law School, University of Professional Students Accra and a Managing Partner at WTS Nobisfields
}

\begin{abstract}
A Deposit Protection or Insurance as the name suggests is intended to provide a sustainable funding to reimburse depositors should an insured act(s) be triggered. Over time, it helps build confidence in the financial ecosystem thereby facilitating a strong and robust financial system. Ghana enacted a Deposit Protection Act in 2016 (the "Act") and added some new sections in 2018 aimed at protecting small depositors, and create faith and stability in the financial system. However, the Act in its present form can neither protect small depositors nor build any faith and stability in the financial system in Ghana. It is not suggested that a deposit insurance alone can create a stable financial system but the part envisaged by the Deposit Protection Act in creating a stable financial system is seriously undermined by sections in the Act itself.
\end{abstract}

Keywords: Deposit Protection Act, Ghana

DOI: $10.7176 / \mathrm{JLPG} / 105-06$

Publication date: January $31^{\text {st }} 2021$

\section{Introduction}

This article originally written in early 2018 would first address the institutional and practical challenges that the Ghana Deposit Protection Act, 2016, Act 931 (as amended) was to face before the establishment of the Ghana Deposit Protection Corporation (GDPC).

It has always been identified that banking systems has often been in turmoil. From the great depression through to the recent financial crises in 2008-2010. ${ }^{1}$ History has however, provided us lessons over the years as to how we can safely deal with such turmoil when they rear their heads. However, without some understanding of banking history according to Carnell, ${ }^{2}$ many elements of banking regulation appear "arbitrary, capricious, even perverse."3 Unfortunately, many of the elements have not work as expected. That as a result, in and around 1929 bank failures were isolated events. "But in 1930 a rash of bank failures in the US Midwest and South sparked what economist Milton Friedman and Anna Schwartz called a 'contagion of fear' among depositors."4 Fast forward to 2007, where large credit growth in the banking system, which is also associated with high appreciation of real estate values and ultimately a collapse in real estate values. "Taxonomically, that is the genre of [the] crises" ${ }^{5}$ that cause bank runs and its attendant need for deposit insurance in the US in the 1930s. Since a financial system are interconnected, ${ }^{7}$ what happens in the US has direct or indirect relationship with financial system of Ghana. Most of the issues directly impact on the financial health of Ghana and therefore solutions elsewhere are brought home for implementation. "[During and after the] recent [global financial crisis between 2007-2008], some countries introduced new deposit insurance schemes and others extended the scope and coverage of their existing schemes to restore confidence in their banking systems." ${ }^{8}$ For instance, Australia and Singapore introduced explicit deposit insurance to their banking systems for the first time, whereas Spain and the US increased the limit on the amounts that are covered by deposit insurance. Other countries increased the scope of securities and bank liabilities guaranteed. The world bank estimate that over 107 countries have some form of explicit deposit insurance scheme in place as of 2016. ${ }^{9}$ Ghana is on that list. This paper seeks to examine Act 931 to see if it does address the problems

\footnotetext{
${ }^{1}$ Carnell, et al, The Law of Financial Institutions, $5^{\text {th }}$ Edition, Wolters Kluter Law Business, 2013

${ }^{2}$ Carnell et al Ibid, providing an overview on American Banking jurisprudence.

${ }^{3} \mathrm{Ibid}$.

${ }^{4}$ Ibid

${ }^{5}$ See generally, The Future of Financial Regulation, John D. Morley and Roberta Romano John M. Olin Center for Studies in Law, Economics, and Public Policy Research Paper No. 386 Yale Law School, National Bureau of Economic Research (NBER), European Corporate Governance Institute (ECGI). This paper can be downloaded without charge from the Social Science Research Network Paper Collection at: http://ssrn.com/abstract $=1415144$

${ }^{6} \mathrm{Ibid}$.

${ }^{7}$ Crude oil prices, credit ratings, Sovereign bonds, IMF, aid and Grants from donor counties etc all impact on the Ghanaian economy.

8 Anginer, Deniz; Bertay, Ata Can (2019): Deposit Insurance, ifo DICE Report, ISSN 2511-7823, ifo Institut - Leibniz-Institut für Wirtschaftsforschung an der Universität München, München, Vol. 17, Iss. 1, pp. 3-8. See also Charles W. Calomiris The Journal of Economic History Vol. 50, No. 2 (Jun., 1990), pp. 283-295 (13 pages) Is Deposit Insurance Necessary? A Historical Perspective

${ }^{9}$ Ibid.
} 
envisaged under the Act.

\section{The Concept and Rationale for Deposit Protection (DP)}

Deposit insurance (or protection) covers losses that depositors might otherwise suffer when their Insured Depository Institutions (IDIs) fail. The first ever deposit protection scheme is the Federal Deposit Insurance Corporation (FDIC) which came into existence in response to the banking crisis of the Great Depression. "President Franklin D. Roosevelt signed legislation creating the FDIC in 1933." The FDIC gave each depositor $\$ 2,500$ in coverage. $^{2}$ Since then, the amount of federal deposit insurance coverage has increased significantly, and the underlying principles of protecting depositors and promoting faith in the stability of the U.S. banking system remain the same [emphasis].

It is widely accepted that banks play a very important financial intermediary role in any economy. This role is heavily regulated ${ }^{3}$ from the commencement of the banking business, that is, licensing, and supervision (monthly reports and visitations by officials of BoG) during the operations of the bank.

The regulation of banks has been supported by many in the past including Adam Smith who, generally is not a fan of government controls but strongly advocated that "banks redeem all notes in specie upon demand."4 The term specie is used in contradiction to paper money, which in some countries is emitted by the government, and is a mere engagement which represents specie. Bank paper in the United States is also called paper money. Specie is the only constitutional money in that country. ${ }^{5}$

It is needless to state the role played by banks as financial intermediaries providing transaction services with demand debt; ${ }^{6}$ their susceptibility to runs and panics; their role in creating and destroying money; and their custodianship of the payment system. ${ }^{7}$ In fact, a bank's susceptibility to runs is the main reason why deposit protection is necessary ${ }^{8}$. All customer deposits be they current, savings or time deposit accounts are called debts to the banks. That is, the deposits are liabilities that the bank invariably owes to its customers. A bank uses the deposits received from customers to advance loans, and grant overdrafts ${ }^{9}$ to persons that it carries out business with. In order for banks to be able to serve their customers, they need to maintain a fine balance between customers' deposits and the ones they have given out as loans. This is called reserves. Every business enterprise uses some form of reserves to some extent. As a matter of life, ordinary people like all of us uses reserves by keeping some cash for immediate needs and putting others into longer term use. Because most firms and individuals can safely predict their cash needs, they are able to put some into illiquid projects. But banks cannot know for certain how much of their debt will become due on any given day because most of their debt takes the form of deposit payable on demand..$^{10}$ It would be easy for banks to keep all their deposits in the vault awaiting customers' withdrawal but vault money does not earn interest. Banks would then lose their most important income, which is interest on loans and other investments. This is why centuries ago banks learned a wonderful secret of keeping just a handful of the cash at hand to pay off demand deposit. ${ }^{11}$

Therefore, banks survive when one depositor is depositing funds, another is taking out and because these two acts are independently driven, the aggregate demand and supply are predictable. ${ }^{12}$ But this predictability evaporates during runs ${ }^{13}$. Depositors who would otherwise have left their money in the bank withdraw it at once. In view of the above, if most depositors in a single day decide to withdraw large amount of money, there would be a total chaos and the bank cannot find all the money needed for them on a single day since some of the money

\footnotetext{
${ }^{1}$ See generally, Transcript of Speech by President Franklin D. Roosevelt Regarding the Banking Crisis March 12 , 1933 available at: https://www.fdic.gov/about/history/3-12-33transcript.html

${ }^{2}$ President Franklin D. Roosevelt signed a legislation creating the Federal Deposit Insurance Corporation (FDIC) in 1933. The first federal deposit insurance, available as of January 1, 1934, gave each depositor \$2,500 in coverage.

${ }^{3}$ In the case of Ghana by the Central Bank, ("Bank of Ghana") by virtue of Article 183 (2) (c) of the 1992 Constitution of Ghana, which provides that; the Bank of Ghana shall encourage and promote economic development and the efficient utilization of the resources of Ghana through effective and efficient operation of a banking and credit system in Ghana (emphasis).

${ }^{4}$ Ales, L., Carapella, F., Maziero, P., \& Weber, W. E. (2008). A Model of Banknote Discounts. Journal of Economic Theory, 142 (1), 5-27. http://dx.doi.org/10.1016/j.jet.2006.10.010

${ }^{5}$ John Bouvier, Law Dictionary, Adapted to the Constitution and Laws of the United States. 1856.

${ }^{6}$ Jose Luis Molina-Borboa; Bernardo Luis Bravo-Benitez, The role of Financial Market Infrastructures in Financial Stability, IGI Global,2018.

${ }^{7}$ Carnell, et al, The Law of Financial Institutions, $5^{\text {th }}$ Edition, Wolters Kluter Law Business, 2013

${ }^{8}$ Besley T., Handbook of Development Economics edited by Hollis Burnley Chenery, T.N. Srinivasan, J. Behrman, Dani Rodrik, T. Paul Schultz, John Strauss, 1988

${ }^{9}$ Unused Bank Overdrafts: Their Implications for Monetary Analysis and Policy, International Monetary Fund. Research Dept. January 1968.

${ }^{10}$ Carnell, et al, Ibid

11 Ibid

${ }^{12}$ See Richard A. Werner, Can banks individually create money out of nothing? - The theories and the empirical evidence., International Review of Financial Analysis Volume 36, December 2014, Pages 1-19.

${ }^{13}$ Quoting from the Cornell University publication on "Bank-runs, Information Cascades, and The Great Depression." Justin Pritchard had described the phenomenon as "a bank run occurs when a large number of customers withdraw their deposits from a bank at the same time, usually because of fears that a bank is or will become insolvent. Customers generally request cash and may put the money into government bonds or other institutions they believe to be safer."
} 
would have been advanced to other customers as loans, overdrafts and on projects and have not been paid back; the bank can come to its knees within a few days. Again, if the loans and overdrafts are not paid or not paid on time, the bank may be in trouble. It is for these reasons that a certain form of deposit insurance or protection is required to save depositors from losing their life time investment.

In acknowledging that the picture painted in the preceding paragraphs have not been experienced in Ghana before, (at least in recent times), it also follows that deposit protection is not the only medicine to cure bank failures as recent events in Ghana attest.

\section{Ghana and Deposit Protection}

Until the birth of Act 931 as amended, there was no explicit nor implicit deposit insurance in Ghana. This may be because very few banks have become insolvent or gone into official liquidation for which customers or depositors had to be paid out for their deposits in the collapsed financial institution ${ }^{1}$ in a way envisaged by the current Act or the nature of their collapse ${ }^{2}$ and their implications on the economy had influenced the policy of where other bank(s) are made to assume their assets. ${ }^{3}$ In 2017, two banks had their licences revoked due to significantly undercapitalization and this bolden the need to protect small depositors. Although when a financial institution gets into liquidity or insolvent, it is not only a selected customer who suffer. The effect extends to institutional investors, companies and high net worth individuals.

At a glance, the Ghana Deposit Protection $\mathrm{Act}^{4}$ and its amendment forebodes a noble and novel idea (at least in Ghana) where the country has witnessed several bank failures in recent past and depositors have gone home empty handed. However, in jurisdictions ${ }^{5}$ where this type of insurance or protection has been instituted, their operations are very different from that anticipated by Act 931 as amended. The Deposit Protection Act in Ghana is to achieve inter alia the following;

"provide the financial resources needed for the operation of the Scheme particularly for the reimbursement of the small depositors of a member of the Scheme on the occurrence of an insured event in respect of that member'

The primary meaning of the word "reimburse" is "to pay back." It also means to make return or restoration of an equivalent for something paid, expended, or lost; to indemnify, or make whole. ${ }^{8}$ The provision of the financial resources to reimburse "small depositors" when an insured event is activated must therefore remain a never changing commitment and that most depositors must be "reimbursed" should the insured event be triggered but that possibility of not receiving a reimbursement is what has been provided for by the Act 931 as amended.

\section{A Critical Review of Act 931 as amended}

The long title of Ghana Deposit Protection Act, 2016, Act 931 provides that it is an Act;

"...for the establishment of a Deposit Protection Scheme, Deposit Protection Fund, Deposit Protection Corporation and for related matters."

To achieve the intention of the Act espoused in the long title, the Act establishes a Deposit Protection Scheme (the "Scheme") as a form of insurance to protect the deposits of "small depositors". Section 3 of Act 931 which provides for the object of the Scheme states that it is to protect "small depositors" from events that are insurable under the Act, and to support the development of a safe, sound and stable financial market place. This is a twoprong object capable of smooth implementation.

\footnotetext{
${ }^{1}$ In their book; Financial Sector Reforms and Bank Performance in Ghana, 2000, the authors T.O Antwi and E.K.Y Addison had chronicled the history of the Ghana Co-operative Bank (COOP) as having its genesis in the Gold Coast Co-operative Bank, which was established by the Association of Cocoa Co- operative Societies in 1948. Its main objective was deposit mobilisation and financing cocoa purchases by the co-operatives. This bank was closed down by the government in 1961 for political reasons, and its affairs were taken over by the Ghana Commercial Bank. In 1973, it was revived but it began operations only in 1975. This bank has been bedeviled by a small capital base and a poor reputation. In 1986 a share flotation with a target of \#500 million yielded only \#135 million. It could not meet the statutory capital requirement of $6 \%$ of risk-rated assets set by the BOG during 1988 and 1989. It was also removed from the Bank Clearing House System because of liquidity problems, so it arranged to clear its cheques through the NSCB between 1989 and 1992 . The Bank of Ghana suspended operations of the COOP on 30 June 1992 and for two weeks, during which the ownership structure was changed and its legal status changed into a limited liability company (from co-operative ownership). A new management and board were appointed on July 1992 (Ghana Cooperative Bank, Annual Report 1994). The bank was recapitalized by the Bank of Ghana, SSNIT and SIC, diluting the holdings of other shareholders.

${ }^{2}$ Ibid, [T] he pre-1988 banking sector was plagued by high costs, poor services, low profitability, poor loan recovery and the weak capital position of all the state-owned banks. The weak macroeconomic environment of high inflation and negative economic growth compounded the problems of the financial sector. Similar to the recent reforms occasioned by negative capital, lack of corporate governance and unfavorable ratios.

${ }^{3}$ See Ibid, Liquidation of Meridian Bank BIAO and formation of Trust (TTB) which took over all its assets in 1994

${ }^{4}$ See, Act 931(2016)

${ }^{5}$ US, China,Singapore, Switzerland etc

${ }^{6}$ Section 9 of Act 931,2016

${ }^{7}$ See, Philadelphia Trust, etc., Co. v. Audenreid, 83 Pa. 264.

${ }^{8}$ See, Black Law Dictionary $11^{\text {th }}$ Edition.
} 
However, the Act in the present form would not be able to address the first and the easier part of the object, that is, the protection of small depositors (because of the structure of the Act), let alone the second part of the object of the Act which does not lie solely with the establishment of a deposit insurance.

First, the overall goal of the Act should have a non- recourse burden to the taxpayer ${ }^{1}$ as an integral aim, although one may argue that a deposit protection and a safe and sound financial market are all intended for the protection of the taxpayer. Such a conclusion is an indirect public obligation. However, the amended provisions in Act 968 on the sources of funding for the Scheme is aimed at providing enough legal grounds to obtain funds from other sources other than the utilization of the original source of the Corporation ${ }^{2}$ as done by most insurance companies. Most insurance companies heavily rely on their investment ${ }^{3}$ of premiums as a fundamental source of their existence. Provisions in the $\mathrm{Act}^{4}$ to borrow money to ensure the attainment of the objects of the scheme where the Corporation has insufficient funds and financing reimbursement of depositors upon the occurrence of an insured even if fund $A$ and $B$ are not sufficient ${ }^{5}$ does sounds similar to the current receiver functions where public funds are used to pay depositors. It is therefore safe to conclude that the target of small depositors by the Ghana Deposit Protection Act, 2016, Act 931 and a safe and sound financial market place is not intended save the taxpayer from any hardship to be endured but are both for governmental benefit.

Under section 4 (3) of Act 931, membership of the Scheme is automatic upon the grant of a banking or specialised deposit-taking Institution licence by the Bank of Ghana. This in itself is problematic. What this means is that once the Bank of Ghana issues a licence to a bank or a specialised deposit taking institution, that institution would automatically become a member of the Scheme, subject only to the Bank of Ghana informing the Ghana Deposit Protection Corporation (GDPC), established under section 22 of the Act, of the issuance of such a licence without more.

However, for the deposits of depositors to be properly protected in a free market, banks and specialised deposit-taking institutions should be allowed to decide whether they want to join this GDPC or do otherwise (because of the huge financial burden associated with becoming a member). ${ }^{6}$ In some jurisdictions ${ }^{7}$ the option of joining a Deposit Protection Corporation (DPC) is given to the financial institutions. The financial institutions in those countries are therefore provided with options and because of the forces at the market place, their membership (although optional by the enabling legislation), has become compulsory because depositors are informed which of the financial institutions are members of DPC and which ones are not and therefore financial institutions are left with no choice than to become members of DPC and boldly advertise their membership. Therefore, when the opportunity for an amendment presented itself in 2018, there was the need to attempt some reforms to cure some basic birth defects in the Act. Unfortunately, that was not done only provisions for the "paybox" function of the scheme, functions of the Corporation, information confidentiality, effect of cessation, funding sources for the scheme and exceptions of funds of certain persons from being insured were the significant provisions amended or inserted as the case may be.

\section{V. "Small Depositor"}

It is concerning that the identification and definition of a "small depositor" and the amount proposed to be paid by the Scheme are both unknown and inadequate. The Act's object is to protect "small depositors" from losses incurred by depositors as a result of an insurable event ${ }^{8}$. Section 53 of Act 931 attempts to define a "small depositor" "o be a variable entity. That is, it is the Board of the GDPC that determines who a small depositor is, such a person (both natural and juridical) at any time. This could mean that "a small depositor" is a moving constant and not be a constant variable. This is a strange provision for an "insurance policy". All over in the insurance world, persons intended to be covered under any insurance scheme must be an identified person or group of persons. Since this provision goes a long way to resolve one of the cardinal principles for the establishment of the scheme, the category of "small depositors" need not be left for the Board but must be determined by Parliament and made knowable at any time.

Whereas the identification of this "small depositor" remains unknown or unascertained, the payment of a

\footnotetext{
${ }^{1}$ Sections 24(j)and (1) of Act 931 (as amended) provides for borrowing from non-member institutions to finance either the attainment of the objects of the scheme or reimbursement of insured depositors.

${ }^{2}$ Sections 24 (j) and (1) of Act 968.

${ }^{3}$ It in most business ventures or real estate, or otherwise lay it out, so that it may produce a revenue or income. See, Drake v. Crane. 127 Mo. S5, 29 S. W. 990, 27 L. It. A. 653; Stramann v. Scheeren, 7 Colo. App. 1, 42 Pac. 191; Una v. Dodd, 39 N. J. Eq. 180.

${ }^{4}$ Section 24(4) (j).

${ }^{5}$ Ibid.

${ }^{6}$ There are extensive provisions on the payment of regular premiums and a percentage of capital to be paid to the GDPC.

${ }^{7}$ Several countries have different modes of implementing their deposit protection or insurance. For instance, Brazil has two such deposit insurance while Canada and Germany have 9 of such schemes including provincial ones with Japan operating different schemes for financial institutions operating in different sectors of the economy. That is, there is a different deposit insurance for financial institutions operating in the agriculture and fisheries sectors separate from those who are into commerce.

${ }^{8}$ Section 3 of Act 931(2016).

${ }^{9}$ As a person who holds a deposit that the Board has determined to be small.
} 
coverage limit of Six Thousand Two Hundred Fifty Cedis (GHS 6,250.00) in the case of banks and One Thousand Two Hundred and Fifty (GHS 1,250) for other specialized deposit-taking institutions ${ }^{1}$ provides a hint to the public who the "small depositors" were at the time of the enactment in 2016. Therefore, small depositor is a person whose deposit falls within the threshold amount provided by the Act. Be that is may, the amount proposed to be reimbursed should an insured event triggers, appears to be woefully inadequate now and shall be even worse should the value of the amount be eroded by inflation over time. ${ }^{2}$ This particular point is fortified by the recent actions of the receiver of the five collapsed banks and other micro finance institutions, when the receiver had earlier set a target of Ten Thousand Cedis (GHS 10,000.00) as the payment limit and later had to increase the limit to Twenty Thousand Cedis(GHS 20,000.00) after failing to meet majority of the deposit of depositors ${ }^{3}$ and now Seventy Thousand Cedis(GHS 70,000). Therein lies partly the reason why membership must not be automatic. If a scheme is to protect small depositors with a limit of Six thousand two hundred and fifty Cedis (GHS 6,250.00) circa, then all deposits above the said threshold would not be protected and therefore Banks and Special DepositTaking Institutions whose clients balances are well above the above threshold, need not be members or need not part take in a scheme that only covers only a fraction of deposits. It seems equally wrong to pay premium on all deposits ${ }^{4}$ when only a fraction of such deposit is catered for under the Act.

The above situation, may make the scheme unattractive for both the insured and deposit taking institutions. It may be partly the reason why the scheme itself is unable to tell Ghanaians their existence after several months ${ }^{5}$. An "insurance" or a "protection" for that matter, is to provide a minimum "indemnity, guarantee or assurance to put the insured in the same position which she was immediately prior to the happening of the uncertain event." It appears to the authors that the Act fails a simple test for what an insurance must do for the insured.

Much as it is recognized, that the Board of the Corporation has the mandate to revise upward the amount reimbursable three years (3) after the commencement of the Corporation, ${ }^{7}$ it thus appears that the Board of the Corporation is not properly clothed with the power to undertake such act though the parent Act says so. This is because a Board of a Corporation cannot amend an Act of Parliament on its own ${ }^{8}$ despite the say so of the Act that empowers it. ${ }^{9}$ It is clear such a provision is to resolve the constant depreciation of the value of the cedi that the Act provide for the occasional upward review without recourse to Parliament. However, a better resolution of the constant depreciation of the cedi problem could be cured by a regular revision of the covered amount payable by the Board and not explicit mention of the coverage in section 20 of the Act so that the Board can have the proper power not the current situation. In its current form, with the covered amount mentioned in the Act, the Board cannot do anything except to seek an amend to the Act again. ${ }^{10}$ It is recommended that a proper research be conducted, or better still, the BoG by virtue of its prestigious position can come up with a figure that may better resonate with Ghanaians. After all, it is not difficult to obtain an average balance of bank and non-bank customers balances. Better still, a percentage ${ }^{11}$ of deposit be used as the amount payable. The occasional upward revision by the Corporation's board is not the way forward and any process brought before the Supreme Court to pronounce on it will win day since same amount to

\footnotetext{
${ }^{1}$ Section 20 (3) (a) and (b) of Act 931.

${ }^{2}$ Laws are mostly made with future events in mind. In countries with ever eroding value of their currencies, the trend has often been to quantify money value in terms of units percentage of deposit so that the value can remain stable for a reasonably foreseeable period.

${ }^{3}$ The receiver announced that "Based on the total number and value of claims received in the receiverships of these MFCs at the extended deadline date for claims submission on Friday, September 27, 2019, the Receiver wishes to announce an increase in the capped payment from GHC10, 000 to $G H \boldsymbol{c} 20,000$ per depositor, to all depositors whose claims have been validated and accepted with immediate effect". [accessed at https://www.graphic.com.gh/business/business-news/microfinance-customers-can-access-gh-20-000-of-funds.html on May 29, 2020] emphasis supplied.

${ }^{4}$ Sections 14 and 15 provides for the payment of $0.1 \%$ on paid up capital and an annual premium on average deposit of member institutions. ${ }^{5}$ The website of the Ghana Deposit Protection Corporation says feasibility of such a scheme was done in 2012 , the Act was passed in 2016 and an amendment in 2018, Yet very few persons are aware of them and the players in the industry are unwilling or cannot understand their birth.

${ }^{6}$ Builders Supply Co. v. McCabe, $366 \mathrm{~Pa} .322$ (Pa. 1951). The court expanding the term indemnity as a compensation in money or property for a loss suffered. It also means a contract to save another from the legal consequences of the conduct of one of the parties or of a third person. It is also an agreement whereby one party agrees to secure another against an anticipated loss or damage. . Indemnity can also be a right which insures to a person who, without active fault on his/her own part, has been compelled, by reason of some legal obligation, to pay damages occasioned by the initial negligence of another, and for which s/he himself is only secondarily liable.

${ }^{7}$ Section $20(8)$ of Act 931 of 2016

${ }^{8}$ Clause 11 (7) (a) of the Constitution 1992, provides that; Any Order, Rule or Regulation made by a person or authority under a power conferred by this Constitution or any other law shall be laid before Parliament. This means that no changes to the Act could be made by the Board without Parliamentary approval

${ }^{9}$ An attempt to increase or decrease the reimbursable amount, would mean an amendment to the Act of Parliament.

${ }^{10}$ See, note 45 supra. The Act was amended in 2018 two years after the enactment of the parent Act in 2016.

${ }^{11}$ During the enacting phase of FDIC in 1932, the US Congress had had to discuss a percentage of deposit coverage by the insurance. Every five years, the FDIC and the (National Credit Union Administration) NCUA must jointly decide whether to increase deposit insurance coverage for inflation. If they do, they must round any increased coverage down to the nearest $\$ 10,000$. 12 U.S.C $\S 1821$ (a) (1) (F).
} 


\section{Disparity in Insurable Amounts}

Perhaps one critical creation in the Ghanaian Deposit Protection Act is the differences in the insurable coverage between Universal Banks and other Specialised-Deposit-taking Institutions (SDIs). That is, customers of Universal Banks are covered up to six thousand, two hundred and fifty Cedis (GHC6,250) and those of other Non-Banking institutions are covered up to one thousand, two hundred and fifty Cedis (GHC1,250). ${ }^{1}$ It is difficult to fathom the intention of the framers since such intention is neither clear on the face of the Act nor accompanied ${ }^{2}$ the Act. Is it the case that those who operate as SDI are less risky or that the persons who patronize their services require less protection? It is perhaps true that when an activity is brought under the deposit insurance safety net, "the production process for that activity and the resulting set of choices available to consumers and businesses may be altered significantly. For example, certain investment and lending decisions of insured institutions may be based more upon regulatory considerations than market incentives, and such distortions may diminish social welfare or productive capacity, or both." It also true that the presence of a high value insurance cover can result in high moral hazard. ${ }^{4}$ Grossman found that in the 1900's when thrifts were insured, they took more risk than their uninsured counterparts. A research conducted in Bolivia showed the tendency of banks conducting sub-prime loans, ${ }^{5}$ when their deposits were insured, thereby putting the deposit insurance scheme at a higher risk. Be that as it may, such reckless risk taking can be overcome with differential premium pricing. Many of the SDI's are into equally high-risk businesses. In fact, they take customers that Universal Bank reject. They often play in the lower end of the customer value chain where the risk level is very high. People often cite the "reason for requiring such a separation [in the reimbursable amount] as the fear that a non-banking operation could expose a bank to greater risk of failure." Some have argued that some non-bank activities may be less risky than traditional banking activities, that some risks may be difficult to detect or monitor without some degree of corporate separation. A related reason for requiring the separation of coverage of non-banking activities from banking activities is to prevent banks from using deposits insured by the government to fund these activities.

However, it is difficult to find any empirical data to support such a stance in the Ghanaian law. Globally, and for reasons already cited above, deposit insurance has come to stem a systemic defect of a financial system. A point could be made that between the two broad institutions, banks enjoy some advantage from their access to the Bank of Ghana "lender of last resort" coupled with the fact that they can use funds obtained from their relationship with the Bank of Ghana to do business with the SDI. This alone gives universal bank undue advantage over their SDI counterparts.

A disparity in the coverage amounts create distortions that may skew the decisions of market participants away from the most productive choices.

\section{VII.Quantity or Quality Deposits Dichotomy}

One major problem of a DP is the likelihood to create moral hazards ${ }^{7}$. Saunders defines moral hazard in this context as "The loss exposure faced by an insurer when the provision of insurance encourages the insured to take more risks." ${ }^{8}$ In common usage, moral hazard infers a conscious malicious, even illegal, motivation, versus an unconscious behavior change. It may also refer to circumstance that increases the likelihood of a loss, or abnormal loss. "[Typically, due to a change in an insurance policy applicant's behavior after policy issuance,...]... incentives

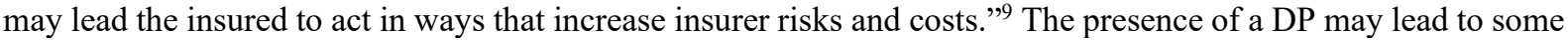
institutions engaging in is risky business because another institution will underwrite the risk should the one under taking the risky venture fails. That is perhaps why the funding source for the Corporation comes from both a percentage of capital and average deposit. There is also an additional opportunity for the Corporation to charge members a differential premium for their risks. ${ }^{10}$

However, an important point in this analysis is the quantity verses quality of deposits angle of the law. It is

\footnotetext{
${ }^{1}$ Cf note 41 .

${ }^{2}$ Section 10 of Act 792, Interpretation Act,2009 provides a tall list of aids to interpretation or construction which includes explanatory memorandum and pre-parliamentary materials relating to the enactment.

${ }^{3}$ See, page 227, https://www.bis.org/publ/plcy07o.pdf

${ }^{4}$ Grossman, Richard S. 1992. "Deposit Insurance, Regulation, and Moral Hazard in the Thrift Indus- try: Evidence from the 1930's." American Economic Review 82: 800-821.

${ }^{5}$ Ioannidou, Vasso P and María Fabiana Penas. 2010. "Deposit Insurance and Bank Risk-Taking: Evidence from Internal Loan Ratings." Journal of Financial Intermediation 19(1): 95-115.

${ }^{6} \mathrm{Ibid}$, note 53

${ }^{7}$ Tracing the genesis of the term moral hazard as being of insurance origin which deals with situations when, for the existence of an insurance policy people refuse to take the needed risk, David Rowell and Luke B. Connelly in The Journal of Risk and Insurance, 2012, Vol 179 N0.4. 1051-1075.

${ }^{8}$ See GILLIAN GARCIA DEPOSIT INSURANCE: OBTAINING THE BENEFITS AND AVOIDING THE PITFALLS INTERNATIONAL MONETARY FUND, MONETARY AND EXCHANGE AFFAIRS DEPARTMENT (1996)

${ }^{9}$ The Journal of Risk and Insurance, Ibid.

${ }^{10}$ The risk that a bank poses to the insurance fund is considered: the probability that the bank will cause a loss to the fund and the likely amount of such loss. Section 16 of the Act and 12 U.S.C $\S 1817$ (b) (1) (A), (C) of the FDIC.
} 
easy to see that because the amount payable within the threshold is very low, most customers are likely to be captured within the Act thereby benefiting from the establishment of the Fund. On the surface, the thought may seem like a universal adult suffrage, whereby one person has one vote. But financial planning and safe and sound financial system does not operate in that form. Values of banking deposits must drive the law and not number of persons on the bank's books. After all the law is about deposits and not depositors. This reasoning is explained by the many reasons why people may have deposits in financial institutions; personal deposits, savings, investment in the form of fixed deposits, trust accounts, pension fund, insurance company accounts, escrow accounts, letters of credit, ${ }^{1}$ and obligations to other financial instructions. It is also deepened by the type of customers that a financial institution may have; trading companies, sole proprietors, insurance companies, churches, schools, mosques, hotels and restaurants, associations etc. Therefore, with the range of deposits available to financial institutions, the limit "envisaged"2 by the Act would require some revision to make it workable.

\section{VIII.Receiver/Liquidator functions}

The Ghana Deposit Protection Corporation (GDPC) should have as part of its functions a liquidator and or receiver of failed banks and other deposit taking-institutions. This function would be very important to the Corporation because of the substantial funds that are generated through the sales of both tangible and intangible assets so that the other significant provisions in Act $931^{3}$ can be actualized. However, the combined reading of the relevant sections in both Acts 930 and 931 suggest a use of a third-party as a receiver. ${ }^{4}$ It is possible that the Corporation may not have the experience required to perform such a function now, (but until recently, a third-party receiver functions with the magnitude witnessed for the failed banks and micro finance institutions, has not been seen in Ghana), they would be able to build capacity over time. Conversely, a third-party receiver may also not have the extensive experience that the Corporation may amass over time since the Corporation would sit at an advantage position with the regular reports from member institutions beforehand. Therefore, to allow depositors to chase a liquidator or receiver after been reimbursed by the Corporation for balance of their deposits appears to be a task that need not be encouraged since same would be a burden on depositors. There could also be a friction between a third-party receiver and the Corporation especially when the Corporation would be part of the regulatory committee of the third-party receiver.

\section{IX.Conclusion}

Deposit Protection or insurance is to provide some relief for depositors. Failure to provide same in view of the proposed reimbursable amount is not the expectation of the framers of the law. Thankfully, this is one Act that enjoys the support of both the major political parties, at least implicitly. Even if a government may reject it as unsound, it may face irresistible political pressure to protect dispositors of DKM, God is Love and their hues all the same. When thousands or hundreds of depositors have lost their money, the pressure for a bailout can become overwhelming.

The DP must instill the needed confidence in the public to serve the purpose of its creation. Nobody sits for an examination with a foreknowledge of the questions. Anyone that does well in an examination achieves success with adequate preparation. Events that may trigger a reliance on a DP are futuristic and uncertain, therefore the need for a robust scheme that has the capability and credibility to withstand shocks in both the domestic and international markets if need be is a key requirement. At present, the Deposit Protection Act, 2016 does not cover the emerging payment systems and services such as mobile money, issuance of electronic money. ${ }^{5}$ The activities of the mobile money providers and electronic money issuers are regulated by the BOG. These payment system and services provides have stringent minimum capital requirement and may have their licences revoked by the BoG. The activities of mobile money providers constitute "deposit." The DPC Act should be amended to offer protection for customers of mobile money users and persons who may subscribe to electronic money. A reasonable compensation should be paid for depositors in the event that a Bank or SDI or PSP (Mobile Money provides and

\footnotetext{
${ }^{1}$ E.g . see generally FDIC v. Philadelphia Gear Corp., 476 U.S. 426 (1986), where the US Supreme ruled that a standby letter of credit backed by a promissory note does not constitute a deposit but letters of credit simplicita does.

${ }^{2}$ The Act has not been triggered and therefore enough opportunity to rework it to increase the payable amount to take inflation and effect of exchange rate depreciation on the Ghana Cedi.

${ }^{3}$ Section 20(9) provides that "Where the amount paid by the Corporation as compensation to an insured depositor is less than the amount credited to the account of the depositor that depositor may recover the difference between the amount paid and the amount credited to the account of the depositor from the liquidator or receiver of the bank or specialised deposit taking-institution.

${ }^{4}$ Section 123 of Act 930 (1) Where the Bank of Ghana determines that the bank or specialised deposit-taking institution is insolvent or is likely to become insolvent within the next sixty days, the Bank of Ghana shall revoke the licence of that bank or specialised deposit-taking institution.

(2) The Bank of Ghana shall appoint a receiver at the effective time of revocation of the licence under subsection (1).

(3) The receiver appointed under subsection (2), shall take possession and control of the assets and liabilities of the bank or specialised deposittaking institution.

${ }^{5}$ For the example, the Payment systems and Services Act, 2019, Act 987 (came into force 13 May 2019) require mobile money and issuers of electronic money to register with the BoG.
} 
Electronic Money Issuers) licence is revoked by the BoG.

It is therefore a good incentive for depositors to be assured a coverage of an appreciable percentage of their deposits than the current limit in the Act. Policy makers must quickly start working on a review of some aspects of the law before the D-day for it shall surely come and we do not have to be caught off guard.

\section{REFERENCES}

\section{Books}

Antwi T.O and Addison, E.K.Y. (2000), Financial Sector Reforms and Bank Performance in Ghana.

Carnell, et al, (2013),The Law of Financial Institutions, $5^{\text {th }}$ Edition, Wolters Kluter Law Business.

John Bouvier, Law Dictionary (1856), Adapted to the Constitution and Laws of the United States.

Black Law Dictionary $11^{\text {th }}$ Edition (2019).

Besley T. (1988), Handbook of Development Economics edited by Hollis Burnley Chenery, T.N. Srinivasan, J. Behrman, Dani Rodrik, T. Paul Schultz, John Strauss.

\section{Articles}

Garcia, Gillian, Deposit Insurance: Obtaining the Benefits and Avoiding the Pitfalls International Monetary Fund, Monetary and Exchange Affairs Department (1996)

Rowell, David and Connelly, Luke B. (2012), The Journal of Risk and Insurance, , Vol 179 N0.4. 1051-1075.

Grossman, Richard S. (1992). "Deposit Insurance, Regulation, and Moral Hazard in the Thrift Indus- try: Evidence from the 1930's." American Economic Review 82: 800-821.

Jose Luis Molina-Borboa; Bernardo Luis Bravo-Benitez, The role of Financial Market Infrastructures in Financial Stability (2018), IGI Global.

Deniz, Anginer,; Bertay, Ata , Can (2019): Deposit Insurance, DICE Report, ISSN 2511-7823, Institut - LeibnizInstitut für Wirtschaftsforschung an der Universität München, München, Vol. 17, Issue. 1, pp. 3-8.

Ioannidou, Vasso P and María Fabiana Penas. (2010). "Deposit Insurance and Bank Risk-Taking: Evidence from Internal Loan Ratings." Journal of Financial Intermediation 19(1): 95-115.

Calomiris, Charles W. The Journal of Economic History Vol. 50, No. 2 (Jun., 1990), pp. 283-295 Is Deposit Insurance Necessary? A Historical Perspective.

Unused Bank Overdrafts: Their Implications for Monetary Analysis and Policy, International Monetary Fund. Research Dept. January 1968.

Werner, Richard A. (December 2014), Can banks individually create money out of nothing? - The theories and the empirical evidence., International Review of Financial Analysis Volume 36, Pages 1-19.

\section{Websites}

Ales, L., Carapella, F., Maziero, P., \& Weber, W. E. (2008). A Model of Banknote Discounts. Journal of Economic Theory, 142 (1), 5-27. http://dx.doi.org/10.1016/j.jet.2006.10.010.

Morley John D. and Roberta Romano John M. The Future of Financial Regulation, Olin Center for Studies in Law, Economics, and Public Policy Research Paper No. 386 Yale Law School, National Bureau of Economic Research (NBER), European Corporate Governance Institute (ECGI).: http://ssrn.com/abstract=1415144

\section{Cases}

Builders Supply Co. v. McCabe, 366 Pa. 322 (Pa. 1951)

FDIC v. Philadelphia Gear Corp., 476 U.S. 426 (1986).

Philadelphia Trust, etc., Co. v. Audenreid, 83 Pa. 264.

\section{Constitution and Statutes}

Banks and Specialised Deposit-Taking Institutions Act, 2016 (Act 930).

Ghana Deposit Protection Act, 2016 (Act 931).

Ghana Deposit Protection (Amendment) Act, 2018 (Act 968) .

Interpretation Act,2009 (Act 792).

Constitution 1992 of Ghana

Federal Deposit Insurance Act (12 U.S.C § 1817 (b) (1) (A), (C)

Payment Systems and Services Act, 2019, Act 987 